\title{
The role of economic freedom and clean energy in environmental sustainability: implication for the G-20 economies
}

\author{
Andrew Adewale Alola ${ }^{1,2} \cdot$ Uju Violet Alola ${ }^{3,4} \cdot$ Saffet Akdag ${ }^{5} \cdot$ Hakan Yildirim $^{6}$
}

Received: 30 August 2021 / Accepted: 11 January 2022 / Published online: 22 January 2022

(c) The Author(s) 2022

\begin{abstract}
With the increasing challenge of attaining sustainable balance in socioeconomic-ecosystem activities, the aspects of the global goals are continously being harnesed in order to ensure a sustainable interaction. As an alliance of the United Nations, the G-20 member countries have not only committed to attaining the Sustainable Development Goals 2030, the alliance body has further fostered frameworks that are targeted at advancing global economic and environmental sustainability. Within this context, the current study examined the environmental sustainability effects arising from the economic freedom prowess in the panel of the G-20 economies over the period 2000-2016. Among the sparse studies, the study employed the indices of economic freedom: freedom to trade internationally, regulation, sound money, legal framework, and property right and alongside the real income and renewable energy consumption as explanatory indicators. With the result of the difference- and two-step system GMM (generalized method of moments), the legal system and property right, sound money, freedom to international trade, and regulatory efficiency are detrimental to the panel countries' environmental quality. Although this is likely to be untrue for countries that have advanced their climate actions and especially the Sustainable Development Goals (SDGs) 2030, it suggests a dearth in the SDGs achievement among the developing and emerging economies. Moreover, it probably shows the depth of traditional or business-as-usual practices (such as the lack of sustainable economic and environmental practices) and the socioeconomic system that are obtainable in most of the developing and emerging economies. Thus, the study put forward tangible policies that are essential for governance and toward attaining desirable country-specific SDGs.
\end{abstract}

Keywords G-20 · Clean energy · Environmental sustainability $\cdot$ Sustainable development $\cdot$ Economic freedom

\section{Introduction}

The persistence drive toward a sustainable environment and development in spite of the dimensions of global challenges could only have yielded a relatively desirable outcome among

Responsible Editor: Ilhan Ozturk

Andrew Adewale Alola

andrew.alola@uwasa.fi

Uju Violet Alola

uvalola@gelisim.edu.tr

Saffet Akdag

ekonomisyen@yahoo.com

Hakan Yildirim

hayildirim@gelisim.edu.tr

1 Department of Economics, School of Accounting and Finance, University of Vaasa, Vaasa, Finland

2 Department of Economics and Finance, South Ural State University, Chelyabinsk, Russia the advanced economies. Although a few of the G-20 and G-7 member countries have consistently experienced economic growth in the last decade, the serious threat to environmental quality arising from the global warming has remained one of the greatest challenge to the sustainable development. Similarly, the increasing human exploitation of natural resources

3 Department of Tourism Guidance, Faculty of Economics, Administrative and Social Science, Istanbul Gelisim University, Istanbul, Turkey

4 Department of Management, South Ural State University, Chelyabinsk, Russia

5 Department of Banking and Finance, Faculty of Applied Sciences, Tarsus University, Tarsus, Turkey

6 Department of Logistic Management, Istanbul Gelisim University, Istanbul, Turkey 
is mounting persistent pessure on the natural eclogical environment. These actions have resulted to a number of ecological complications such as environmental degradation, ecological degradation, and climate warming that are standing as threats to the economic growth and development globally (Alola et al. 2019c; Alola and Joshua 2020; Ulucak and Khan 2020; Wang et al. 2020; Adedoyin and Zakari 2020; Adedoyin et al. 2021). For instance, the report of World Energy Outlook (WEO) in 2017 linked the premature deaths of about 3 million to energy pollution especially from non-renewable energy sources. In specific, pollutant emissions from the use of fossil fuels, coal, and tradition cooking fuel from firewood among are increasingly constituting the highest source of emissions, thus causing serious environment to degradation.

More importantly, the environmental Kuznets curve (EKC) hypothesis depicts the (tarde-off and/or U-shaped) relationship between economic growth and environmental degradation in such a way that an increase in the later is triggered by an increase in the former at the early stage of development until a thresshold level is attained when the association between the two variables becomes negative (Grossman and Krueger 1991; Stern 2004). Following this perspective, the U-shaped relatiosnhip between economic output and environmental sustainabiity has been further conceptualized by augmenting the relationship with other social and economic indicators such as energy, trade, tourism, technology, health, and agriculture (Katircioğlu 2014; Shahbaz et al. 2014; Apergis and Ozturk 2015; Al-mulali et al. 2015; Ozturk et al. 2016; Higón et al. 2017; Asongu 2018; Sarkodie et al. 2020; Alola and Ozturk 2021).

However, the need to achieve a more rapid sustainable development should align with the enhancement of environmental quality and the ecosystem capabilities which plays a key role in human activities. In addition, the drive toward achieving the rapid economic growth amidst sustainable environment has further deepened the global need to preserve the world ecological footprint (EF), thus reducing the humans' endangering activities. The ecological footprint as accounted by the framework of the Global Footprint Network (GFN) is measured as the demand for nature by humans and which amount to the number of natural resources humans use to support and meet their needs. The EF takes into consideration the comparison of the quantity of biologically produced goods that are available for human consumption and the biologically productive area of the geographical location under consideration. Considering that increasing number of countries is experiencing a deficit $\mathrm{EF}$, this suggest the desirability of countries to shift toward the consumption of biodegradable or re-usable resources in the value chain of economic activity rather than non-renewable resources such as the fossil oil and other carbon-laden fuels.

For instance, among the G-20-member countries (Argentina, Australia, Brazil, Canada, China, France, Germany, India, Indonesia, Italy, Japan, Mexico, Republic of Korea (South Korea),
Russia, Saudi Arabia, South Africa, Turkey, the UK, the USA, and the European Union (EU)), only 5 countries and the EU are currently not showing deficit in the $\mathrm{EF}$ (Global Footprint Network 2020). Specifically, the degree (in percentage) of how much the $\mathrm{EF}$ is greater than biocapacity is obviously severe in 14 of the G-20 economies: China (278\%), France (87\%), Germany (199\%), India (173\%), Indonesia (32\%), Italy (371\%), Japan (672\%), Mexico (122\%), Republic of Korea (797\%), Saudi Arabia (1480\%), South Africa (229\%), Turkey (133\%), the UK (301\%), and the USA (122\%). Interestingly, the above evidence is associated with the fact that the G-20 economies account for about $90 \%$ of the global GDP with the economic organization's population amounting to about $60 \%$ of the world population. Considering the aforementioned motivation and that the G-20 economies contribute about $75 \%$ to the global greenhouse gases (GHGs) emissions (Climate Transparency 2016), the economic organization has further encouraged the members' commitment to climate actions such as to put their carbon footprint under control, thus mitigating climate change and global warming globally.

In view of the above motivation, and as an objective, the current study is designed to examine the role of economic freedom on environmental sustainability amidst the drive for economic prosperity of the G-20-member countries. In order to achieve the desired objective, the study implements clean energy-driven growth (growth induced by renewable energy consumption) in addition to the economic freedom indicators that include legal systems and property rights, sound money, freedom to international trade, and regulation. By employing the ecological footprint as a proxy for environmental sustainability in a unique framework, the generalized method of moments (GMM) is employed for the panel of G-20 economies in a novel approach. Moreover, this study offers a significant contribution to the literature by employing a set of sparsely factors such as law and order and propoerty right, sound money, freedom of international trade, and regulations. Therefore, by exploring the sustainable development and environmental quality drive of the G-20 countries from the perspective of economic freedom, the contributions of the current study to the exising body of knowledge are considered a novel point of observation.

The subsequent sections are arranged in a specified order. The "Methodology," "Findings and discussion," and "Conclusion and policy suggestion" sections present the data and methodlogy, the discussion of the findings, and conclusion of the study, respectively.

\section{Methodology}

\section{Description of indicators}

This study employed the dataset described (see Table 1) that span over the period 2000 to 2016 for the balanced panel of the G-20 economies excluding the EU and Suadi Arabia. 


\section{Model framework}

Several decades ago, Ehrlich and Holdren (1971) and a similar follow-up by Holdren and Ehrlich (1974) both illustrated that the environmental impacts (I) of population growth (P), affluence (A), and technology change ( $\mathrm{T}$ ) could be expressed as IPAT (such that I=PAT). Consequently, York et al. (2003) later modified the IPAT into a stochastic model to imply that the environmental impact can be modeled as STIRPAT (for stochastic impacts by regression on population, affluence, and technology). However, that is not without an arguement that suggest that the importance of environmental impact of human behavior should not be undermined; thus, the study of Schulze (2002) rather advanced the IPAT model as IPBAT where B represents human behavior. Following the above representation of environmental impact, recent studies that augment the STITPAT model have been presented with the incorporation of relevant factors that potentially exhibit environmental impact. In the extant studies, the justification for economic advancement, technological innovation, population, and several aspects of human activities and evironmental-related nexus have been widely covered (Ardito et al. 2019; Cop et al. 2020, 2021; Aldieri et al. 2021).

Following the perspective from the provious studies that ecological footprint appropriately reflects and captures environmental impact relative to other environmental variables such as the greenhouse gas and carbon emissions emissions, the STIRPAT model is augmented by incorporating REG and LSPR as proxy for behavioral factors accordingly.

$\mathrm{EF}=f(\mathrm{EF}, \mathrm{GDPc}, \mathrm{RENE}, \mathrm{LSPR}, \mathrm{SMO}, \mathrm{FT}, \mathrm{REG})$
Primarily, the variables EF, GDPc, and RENE are transformed to natural logarithm while the other variables are employed directly since they are indexes. In additon, other priori tests implied that the variables are integrated after first difference (the result is not supplied for lack of space) and that there is significant evidence of cointegration (see Table 3 in Appendix).

\section{Empirical method}

This study is designed to examine the environmental effects of some selected indicators of economic freedom on the ecological footprint of the panle of G-20 economies. In this study, we settled for the difference GMM and system GMM. The technique is considered approapriate and the best estimation techniques for the study most importantly because the number of cross-section (number of examined countries in the panel), $N=18$, is more than the number of period $T=17$ ). Additionally, this approach is considered as to mitigate the effects of heteroscedasticity and endogeneity of the independent variables in the employed panel dataset. Moreover, the approach makes provisions for lagged endogenous variable as an explanatory variable to avoid the the possibility of endogeneity and also give a robust estimate of a large data set (see Usman et al 2019). However, in this case, we choose the system two-step of the two models ahead of one-step based on suitability because of the indicated diagnostic inference from the autocorrelation and the Sargan tests. The two-step GMM is written as follows:

$\ln E F_{i t}=a_{0}+a_{1} \ln E F_{i t}+a_{2} \ln G D P c_{i t}+a_{3} \ln R E N E_{i t}+a_{4} L S P R_{i t}+a_{5} S M O_{i t}+a_{6} F T_{i t}+a_{7} R E G_{i t}+\varepsilon_{i t}$

Table 1 The description of the variables and statistics properties

\begin{tabular}{|c|c|c|c|c|c|c|c|}
\hline Variable & $\mathrm{EF}$ & GDPc & RENE & LSPR & SMO & FT & REG \\
\hline Measurement & $\begin{array}{l}\text { Global hectare } \\
\text { (Gha) }\end{array}$ & $\begin{array}{l}\text { Per capia } \\
\text { (Constant } 2010 \text { USD) }\end{array}$ & $\begin{array}{l}\text { Thousands } \\
\text { Tonnes }\end{array}$ & $\begin{array}{l}0 \text { to } 10 \\
0=\text { low } \\
10=\text { high }\end{array}$ & $\begin{array}{l}0 \text { to } 10 \\
0=\text { low } \\
10=\text { high }\end{array}$ & $\begin{array}{l}0 \text { to } 10 \\
0=\text { low } \\
10=\text { high }\end{array}$ & $\begin{array}{l}0 \text { to } 10 \\
0=\text { low } \\
10=\text { high }\end{array}$ \\
\hline Source & GFN & WDI & OECD & \multicolumn{4}{|c|}{$\begin{array}{l}\text { Fraser Institute1 Fraser Institute Fraser Institute } \\
\text { Fraser Institute }\end{array}$} \\
\hline \multicolumn{8}{|l|}{ Statistics } \\
\hline Mean & 7.067 & $21,801.61$ & $49,185.97$ & 6.239 & 8.519 & 7.369 & 6.937 \\
\hline Minimum & 4.493 & 443.314 & 758.031 & 3.009 & 3.567 & 3.600 & 4.120 \\
\hline Maximum & 8.450 & $68,150.11$ & $266,484.6$ & 8.795 & 9.887 & 9.367 & 8.973 \\
\hline Standard deviation & 0.799 & $17,802.44$ & $63,580.17$ & 1.453 & 1.381 & 0.930 & 1.137 \\
\hline Skewness & -0.348 & 0.451 & 1.661 & -0.052 & -1.392 & -0.936 & -0.088 \\
\hline Kurtosis & 2.523 & 1.866 & 4.568 & 1.802 & 4.663 & 5.309 & 2.225 \\
\hline Obserrvations & 302 & 302 & 302 & 302 & 302 & 302 & 302 \\
\hline
\end{tabular}

Note: The EF, GDPc, RENE, LSPR, SMO, FT, and REG are respectively the ecological footprint, gross domestic product per capita, renewable energy consumption, law and order and propoerty right, sound money, freedom of international trade, and regulations. Also, Organization for Economic Cooperation and Development is OECD, World Development Indicator (of World Bank) is WDI, and Global Footprint Network is GFN

${ }^{1}$ The economic freedom of the world index has consistently been reported by the Fraser Institute (2018) 
There are two ways of estimating GMM, difference GMM, and system GMM. For the difference GMM, Eq. (1) can be rewritten as follows:

$$
\begin{array}{r}
\ln E F_{i t}-\ln E F_{i, t-1}=a_{1}\left(\ln E F_{t-1}-\ln E F_{i, t-2}\right)+a_{2}\left(\ln G D P_{i t}-\ln G D P_{i, t-1}\right) \\
+a_{3}\left(\ln R E N E_{i t}-\ln R E N E_{i, t-1}\right)+a_{4}\left(L S P R_{i t}-L S P R_{i, t-1}\right) \\
+a_{5}\left(S M O_{i t}-S M O_{i, t-1}\right) \\
+a_{6}\left(F T_{i t}-F T_{i, t-1}\right)+a_{7}\left(R E G_{i t}-R E G_{i, t-1}\right)
\end{array}
$$

The condition for the difference GMM estimator in Eq. (3) is given below:

$E\left(\ln E F_{i, t-z} * \varepsilon_{i, t}\right)=0$, for $z 2001 t=2000,2001$

Difference GMM is an effective estimator to control some distinct features of each of the countries and the endogenous independent variables. However, it could lead result to a biased parameter estimation in small sample space and larger variance asymptotically (Khan et al 2019). To circumvent the problems, another approach is system GMM. The condition for the system GMM for Eq. (2) is given below:

$E\left(\ln E F_{i, t-z}+\varepsilon_{i, t-z-1} * \varepsilon_{i, t}\right)=0$, forz $=1, t=2002 \ldots \ldots 2016$

From Eq. (2) above, EF is the ecological footprint which is the dependent variable in the equation. GDP,
RENE, LSPR, SMO, FT, and REG are the explanatory variables representing economic growth, renewable energy consumption, legal systems and property right, sound money, freedom of trade, and regulation, respectively.

[EF】_(i,t-1) is the first lag of the dependent variable and used as an estimate for measurement of the current year using previous years and $\varepsilon_{-}$it is the stochastic disturbance that put into consideration uncaptured variables among the independent variables. The result of both the difference and system GMM is implied in Table 2.

\section{Findings and discussion}

According to the results obtained and indicated in Table 2, the consistency of GMM estimators is evaluated. The Wald test results implied that one-step models of both difference GMM and system GMM estimators are meaningful as a whole while Sargan test is not valid for over identifying restrictions in related models. Therefore, illustrated models (one-step models of both difference GMM and system GMM) are excluded or ignored. In addition to the two-stage test results, Wald test results show that of both two-step of the difference GMM and system GMM estimators are meaningful as a whole. However, the Sargan test implied that the over identifying restrictions in the system, two-step model is found to be valid. The autocorrelation test also provided additional evidence that shows that there

\begin{tabular}{|c|c|c|c|c|}
\hline \multirow[t]{2}{*}{ Explanatory variables } & \multicolumn{2}{|l|}{ Difference GMM } & \multicolumn{2}{|l|}{ System GMM } \\
\hline & One-step result & Two-step result & One-step result & Two-step result \\
\hline $\mathrm{EF}_{-1}$ & $\begin{array}{l}0.199 \\
(0.000)\end{array}$ & $\begin{array}{l}0.147 * * \\
(0.050)\end{array}$ & $\begin{array}{l}0.268 \\
(0.000)\end{array}$ & $\begin{array}{l}\text { 0.278* } \\
(\mathbf{0 . 0 0 0 )}\end{array}$ \\
\hline $\operatorname{lnGDPc}$ & $\begin{array}{l}0.0369 \\
(0.040)\end{array}$ & $\begin{array}{l}0.0377 \\
(0.158)\end{array}$ & $\begin{array}{l}0.019 \\
(0.082)\end{array}$ & $\begin{array}{l}0.0651 \\
(0.104)\end{array}$ \\
\hline LnRENE & $\begin{array}{l}-0.014 \\
(0.580)\end{array}$ & $\begin{array}{l}0.013 \\
(0.806)\end{array}$ & $\begin{array}{l}0.058 \\
(0.000)\end{array}$ & $\begin{array}{l}\mathbf{0 . 0 8 8} * * \\
(\mathbf{0 . 0 3 8})\end{array}$ \\
\hline Legal systems \& property rights & $\begin{array}{l}0.226 \\
(0.000)\end{array}$ & $\begin{array}{l}0.278^{*} \\
(0.000)\end{array}$ & $\begin{array}{l}0.123 \\
(0.000)\end{array}$ & $\begin{array}{l}\text { 0.189* } \\
(0.000)\end{array}$ \\
\hline Sound money & $\begin{array}{l}0.150 \\
(0.000)\end{array}$ & $\begin{array}{l}0.159 * \\
(0.000)\end{array}$ & $\begin{array}{l}0.140 \\
(0.000)\end{array}$ & $\begin{array}{l}0.094 * \\
(0.034)\end{array}$ \\
\hline Freedom to trade & $\begin{array}{l}0.262 \\
(0.000)\end{array}$ & $\begin{array}{l}0.255^{*} \\
(0.000)\end{array}$ & $\begin{array}{l}0.220 \\
(0.000)\end{array}$ & $\begin{array}{l}0.259 * \\
(0.000)\end{array}$ \\
\hline Regulation & $\begin{array}{l}0.206 \\
(0.000)\end{array}$ & $\begin{array}{l}0.179 * \\
(0.000)\end{array}$ & $\begin{array}{l}0.126 \\
(0.000)\end{array}$ & $\begin{array}{l}0.137 * \\
(\mathbf{0 . 0 0 0})\end{array}$ \\
\hline Wald test & $\begin{array}{l}3653.04 \\
(0.000)\end{array}$ & $\begin{array}{l}1518.85^{*} \\
(0.000)\end{array}$ & $311,832.91(0.000)$ & $\begin{array}{l}443.47 * \\
(0.000)\end{array}$ \\
\hline Sargan test & $\begin{array}{l}240.146 \\
(0.000)\end{array}$ & $\begin{array}{l}12.713 \\
(0.997)\end{array}$ & $\begin{array}{l}373.548 \\
(0.000)\end{array}$ & $\begin{array}{l}10.700 \\
(0.998)\end{array}$ \\
\hline $\mathrm{Ar}_{(1)}$ probability & 0.000 & 0.007 & 0.004 & 0.037 \\
\hline $\mathrm{Ar}_{(2)}$ probability & 0.951 & 0.893 & 0.838 & 0.821 \\
\hline
\end{tabular}
is no autocorrelation between the variables in the AR (2)
Table 2 The result of the difference and system GMM
$* * *, * *$, and $*$ indicate $1 \%, 5 \%$, and $10 \%$ levels of significance, respectively 
process. Foremost, the result of both the two-step (difference and system) GMM implied that the (first) lag of the ecological footprint positively affects the ecological footprint of the panel countries.

Additionally, the results of both the difference GMM and system GMM highlight that GDP per capital affects the ecological footprint positively. However, the impact is not significant; it specifically shows that the difference GMM posited a rise in GDP per capita by $1 \%$ and increases the ecological footprint by $0.038 \%$ while the system GMM indicates that an increase in GDP per capita by $1 \%$ raises the value of the ecological footprint insignificantly by $0.65 \%$. This implies that increasing the individual income level of the people in the G-20 economies will worsen the environmental degradation because it will cause more demand on the country's ecological footprint in G-20 countries. This result partially concurs with the fact that an improved income level of the individual might not necessarily trigger the consumption of goods and services that are detrimental to the environment. However, the result contradict the findings of Alola et al. (2019a, $b, c)$ that found that a rise in the real income in the three largest European states worsens the environmental quality of the countries (France, Germany, and the UK).

Concerning renewable energy consumption, the results obtained from both the difference and systems GMM verify a positive impact of renewable energy consumption on the ecological footprint of the panel of G-20 economies. However, the impact is only significant at $10 \%$ level of significance for the system GMM model. More precisely, a $1 \%$ rise in renewable energy consumption increases the ecological footprint insignificantly by $0.13 \%$ for the difference GMM while the system GMM model shows that a $1 \%$ increase in the renewable energy consumption increases the ecological footprint of G-20 economies significantly by $0.88 \%$. This implies that renewable energy utilization is yet to improve the environmental quality of the G-20 economies. Similar to the recent findings of Alola and Joshua (2020), the reason for this undesirable result could be associated with the fact that the components of renewable energy in most of the examined countries might not be totally from clean energy sources. Alola and Joshua (2020) found a positive relationship between $\mathrm{CO}_{2}$ emissions and renewable energy consumption, first for the lower middleincome economies and secondly for the panel of upper middle, lower middle, low-income, and high-income economies. Moreover, the renewable energy sources are mostly from geothermal, solid biofuels, biogasoline, biodiesels, other liquid biofuels, biogases, and others (Organization for Economic Cooperation and Development, OECD 2020). The results obtained in this regard contradict the findings expressed in the case of the EU countries (Alola et al. 2019b; Bekun et al. 2019; Adedoyin et al. 2020) that posited that renewable energy consumption improves the environmental quality in 16 EU economies. Moreover, there are other related studies that have also supported the negative nexus of renewable energy consumption and environmental sustainability (Bhattacharya et al. 2016; Bekun et al. 2020; Sharif et al. 2020).

Furthermore, the results also confirm that legal systems and property rights have a significant and positive impact on the ecological footprint of the G-20 economies. Specifically, the difference and system GM show that an increase in the legal systems and property rights increases the ecological footprint of G-20 economies significantly. This implies that improving the effectiveness of the judicial, increasing the accountability and independence of the G-20's legal systems in addition to improving the property rights poses threat to the environmental quality of examined economies. The economic intuition can be viewed from the perspective that improved legal system and property right would amount to increased investment and economic opportunities thus accumulating more demand on the ecosystem. It is note mentioning that increased ecological stress will unavoidably prompt more environmental damage. Similarly, we also found a positive and significant impact of sound money on EF across the two-step model employed in the study. This implies that encouragement of sound money (a more stable currency) that neither easily appreciates nor depreciates due to business cycle or economic fluctuations deepens the threats on environmental sustainability of the panel of G-20 economies. Although the result is not desirable, there is high tendency that a more stable currency will be a huge interest to investors, in that more economic activities are triggered in such situation. However, the finding is in contrary to the evidence that was posited by Hashmi and Alam (2019).

Moreover, the results highlight that (freedom to international trade/open market) allowing free trade has a significant and positive impact on the ecological footprint in G-20 economies. The same observation is revealed for the impact of regulations (this constitutes business, labor, and monetary freedom) on the ecological footprint. This implies that allowing a free international trade and regulatory efficiency in the panel countries worsens the environmental quality. In both circumstances (when international trade is unhindered and high regulatory efficiency is encouraged), environmental degradation will worsen in G-20 economies especially because trade in environmentally hazardous goods and service is either unhindered or with limited restriction across borders. Except in the case of advanced economies that have consistently incorporated carbo actions as a policy across the economic sectors, the result is an indication that major economic activities of many of the member countries are largely driven by the business-as-usual approaches such as the use of conventional energy. These findings especially that hints on the environmental effect associated with 
regulatory quality, trade openness, and related policy are consistent with the findings of Ahmed and Ozturk (2019, Alola (2019), and Adedoyin et al. (2020).

\section{Conclusion and policy suggestion}

For the first time in the literature, this study explored the economic freedom attributes associated with the G-20 economies from the perspectives of sustainable development vis-à-vis sustainable income and environmental sustainability. In this case, the role of the attributes of legal system and property right, sound money, freedom to international trade, and regulatory efficiency in environmental sustainability over the period of 2000 to 2016 is examined with the generalized method of moments. In order to control for other factors, the real income per capita and renewable energy consumption were utilized alongside the aforementioned economic freedom indicators. Interestingly, the impact of the aforementioned indicators (legal system and property right, sound money, freedom to international trade, and regulatory efficiency) on ecological footprint were all found to be significant and positive in both the two-step difference and system GMM estimations. Considering that these results are not environmentally desirable, relevant policy is essential in the panel countries to

enhance a feasible attainment of the country-specific sustainable environment and development as outlined in the SDGs for 2030.

As a policy, the G-20 countries especially the developing and emerging economies should further incorporate sustainable economic and environmental policies across the sectors of their respective economies. The impact of legal system and property right, sound money, freedom to international trade, and regulatory efficiency on environmental sustainability could be better fashioned with frameworks that are targeted to have a more sustainable outcome. For instance, free international trade/open market and property right policies such as tax exemption or subsidy that encourages new investors and business owners could be adopted by any of the examined countries that are obviously slow toward carbon action commitments. In addition, the implementation of more stringent environmental policy such as the emissions trading system (ETS) and carbon tax across could offer more efficient approach in preventing threat of carbon-outsourcing or carbon leakages. In regard to sound money or the stabilization of the countries exchange (monetary) policy, re-engineering the countries' major sectors on the framework of green economy is expected to provide a more balanced and desirable economy-environmental sustainability mechanism.

\section{Appendix}

Table 3 Evidence of cointegration by Pedroni residual and Kao test

\begin{tabular}{|c|c|c|c|c|}
\hline \multicolumn{5}{|c|}{$\begin{array}{l}\text { Pedroni residual cointegration } \\
\text { Alternative hypothesis: common AR coefs. (within-dimension) }\end{array}$} \\
\hline & Statistic & Prob & Weighted statistic & Prob \\
\hline Panel v-statistic & -1.481 & 0.930 & -2.068 & 0.981 \\
\hline Panel rho-statistic & 4.215 & 1.000 & 4.142 & 1.000 \\
\hline Panel PP-statistic & -2.860 & $0.002^{\mathrm{a}}$ & -3.322 & $0.000^{\mathrm{a}}$ \\
\hline Panel ADF-statistic & -3.844 & $0.000^{\mathrm{a}}$ & -4.274 & $0.000^{\mathrm{a}}$ \\
\hline \multicolumn{5}{|c|}{ Alternative hypothesis: individual AR coefs. (between-dimension) } \\
\hline & Statistic & Prob & & \\
\hline Group rho-statistic & 5.740 & 1.000 & & \\
\hline Group PP-statistic & -4.510 & $0.000^{\mathrm{a}}$ & & \\
\hline Group ADF-statistic & -4.382 & $0.000^{\mathrm{a}}$ & & \\
\hline \multicolumn{5}{|c|}{ Kao residual cointegration test } \\
\hline & & $\mathrm{t}$-Statistic & Prob & \\
\hline $\mathrm{ADF}$ & & -5.824130 & $0.000^{\mathrm{a}}$ & \\
\hline Residual variance & & $8.09 \mathrm{E}-05$ & & \\
\hline HAC variance & & $6.37 \mathrm{E}-05$ & & \\
\hline
\end{tabular}

represents the $1 \%$ statistically significant level 
Author contribution Andrew Adewale alola: conceptualization, investigation, methodology, and corresponding.

Uju Violet Alola: writing-original draft, data curation, and review.

Saffet Akdag: formal analysis, investigation, and methodology.

Hakan Yildirim: writing -original draft.

Funding Open Access funding provided by University of Vaasa (UVA).

\section{Declarations}

Ethics approval Not applicable.

Consent to participate Not applicable.

Consent for publication Not applicable.

Competing interests The authors declare no competing interests.

Open Access This article is licensed under a Creative Commons Attribution 4.0 International License, which permits use, sharing, adaptation, distribution and reproduction in any medium or format, as long as you give appropriate credit to the original author(s) and the source, provide a link to the Creative Commons licence, and indicate if changes were made. The images or other third party material in this article are included in the article's Creative Commons licence, unless indicated otherwise in a credit line to the material. If material is not included in the article's Creative Commons licence and your intended use is not permitted by statutory regulation or exceeds the permitted use, you will need to obtain permission directly from the copyright holder. To view a copy of this licence, visit http://creativecommons.org/licenses/by/4.0/.

\section{References}

Adedoyin FF, Zakari A (2020) Energy consumption, economic expansion, and $\mathrm{CO} 2$ emission in the UK: the role of economic policy uncertainty. Sci Total Environ 738:140014

Adedoyin F, Abubakar I, Bekun FV, Sarkodie SA (2020) Generation of energy and environmental-economic growth consequences: is there any difference across transition economies? Energy Rep 6:1418-1427

Adedoyin FF, Agboola PO, Ozturk I, Bekun FV, Agboola MO (2021) Environmental consequences of economic complexities in the EU amidst a booming tourism industry: accounting for the role of brexit and other crisis events. J Clean Prod 305:127117

Ahmed K, Ozturk I (2019) Effect of trade on ecological quality : a case of D-8 countries, 35935-35944

Aldieri L, Brahmi M, Chen X, Vinci CP (2021) Knowledge spillovers and technical efficiency for cleaner production: an economic analysis from agriculture innovation. J Clean Prod 320:128830

Al-mulali U, Weng-Wai C, Sheau-Ting L, Mohammed AH (2015) Investigating the environmental Kuznets curve (EKC) hypothesis by utilizing the ecological footprint as an indicator of environmental degradation. Ecol Ind 48:315-323. https://doi.org/10.1016/j. ecolind.2014.08.029

Alola AA (2019) The trilemma of trade, monetary and immigration policies in the United States: accounting for environmental sustainability. Sci Total Environ 658:260-267. https://doi.org/10. 1016/j.scitotenv.2018.12.212

Alola AA, Joshua U (2020) Carbon emission effect of energy transition and globalization: inference from the low-, lower middle-, upper middle-, and high-income economies. Environ Sci Pollut Res 1-11

Alola AA, Yalçiner K, Alola UV, Akadiri SS (2019a) The role of renewable energy, immigration and real income in environmental sustainability target. Evidence from Europe largest states. Sci Total Environ 674:307-315. https://doi.org/10.1016/j.scitotenv. 2019.04.163

Alola AA, Bekun FV, Sarkodie SA (2019b) Dynamic impact of trade policy, economic growth, fertility rate, renewable and non-renewable energy consumption on ecological footprint in Europe. Sci Total Environ 685:702-709

Alola AA, Yalçiner K, Alola UV (2019c) Renewables, food (in) security, and inflation regimes in the coastline Mediterranean countries (CMCs): the environmental pros and cons. Environ Sci Pollut Res 26(33):34448-34458

Alola AA, Ozturk I (2021) Mirroring risk to investment within the EKC hypothesis in the United States. J Environ Manag 293:112890

Apergis N, Ozturk I (2015) Testing environmental Kuznets curve hypothesis in Asian countries. Ecol Ind 52:16-22

Ardito L, Petruzzelli AM, Ghisetti C (2019) The impact of public research on the technological development of industry in the green energy field. Technol Forecast Soc Chang 144:25-35

Asongu SA (2018) ICT, openness and CO 2 emissions in Africa. Environ Sci Pollut Res 25(10):9351-9359

Bhattacharya M, Paramati SR, Ozturk I, Bhattacharya S (2016) The effect of renewable energy consumption on economic growth: evidence from top 38 countries. Appl Energy 162:733-741

Bekun FV, Alola AA, Sarkodie SA (2019) Toward a sustainable environment: nexus between $\mathrm{CO} 2$ emissions, resource rent, renewable and nonrenewable energy in 16-EU countries. Sci Total Environ 657:1023-1029. https://doi.org/10.1016/j.scitotenv.2018.12.104

Bekun FV, Yalçiner K, Etokakpan MU, Alola AA (2020) Renewed evidence of environmental sustainability from globalization and energy consumption over economic growth in China. EnvironSci Pollut Res $1-15$

Climate Transparency Report (2016) Analysis of Climate change in G-20 economies

Cop S, Alola UV, Alola AA (2020) Perceived behavioral control as a mediator of hotels' green training, environmental commitment, and organizational citizenship behavior: a sustainable environmental practice. Bus Strateg Environ 29(8):3495-3508

Çop S, Olorunsola VO, Alola UV (2021) Achieving environmental sustainability through green transformational leadership policy: can green team resilience help? Bus Strateg Environ 30(1):671-682

Ehrlich PR, Holdren JP (1971) Impact of population growth. Science 171(3977):1212-1217

Fraser Institute (2018) Economic freedom of the world: 2018 annual report. Fraser Institute

Grossman GM, Krueger AB (1991) Environmental impacts of a North American free trade agreement (No. w3914). National Bureau of economic research

Global Footprint Network (2020). http://data.footprintnetwork.org/? $\mathrm{ga}=2.24572794 .1954376735 .1595343308-81478156.15914$ 66665\#/. (Accessed 21 July 2020)

Hashmi R, Alam K (2019) Dynamic relationship among environmental regulation, innovation, $\mathrm{CO} 2$ emissions, population, and economic growth in OECD countries: a panel investigation. J Clean Prod 231:1100-1109. https://doi.org/10.1016/j.jclepro.2019.05.325

Higón DA, Gholami R, Shirazi F (2017) ICT and environmental sustainability: a global perspective. Telematics Inform 34(4):85-95

Holdren JP, Ehrlich PR (1974) Human Population and the Global Environment: population growth, rising per capita material consumption, and disruptive technologies have made civilization a global ecological force. Am Sci 62(3):282-292

International Energy Outlook (2017) U.S. Energy Information Administration. U.S. Department of Energy, Washington, DC 
Katircioğlu ST (2014) Testing the tourism-induced EKC hypothesis: the case of Singapore. Econ Model 41:383-391

Khan S, Peng Z, Li Y (2019) Energy consumption, environmental degradation, economic growth and financial development in globe: dynamic simultaneous equations panel analysis. Energy Rep 5:1089-1102. https://doi.org/10.1016/j.egyr.2019.08.004

Organization for Economic Cooperation and Development, OECD (2020) Renewable energy (indicator). https://doi.org/10.1787/ aac7c3f1-en (Accessed on 22 July 2020)

Ozturk I, Al-Mulali U, Saboori B (2016) Investigating the environmental Kuznets curve hypothesis: the role of tourism and ecological footprint. Environ Sci Pollut Res 23(2):1916-1928

Sarkodie SA, Adams S, Owusu PA, Leirvik T, Ozturk I (2020) Mitigating degradation and emissions in China: the role of environmental sustainability, human capital and renewable energy. Sci Total Environ 137530

Shahbaz M, Khraief N, Uddin GS, Ozturk I (2014) Environmental Kuznets curve in an open economy: a bounds testing and causality analysis for Tunisia. Renew Sustain Energy Rev 34:325-336

Sharif A, Baris-Tuzemen O, Uzuner G, Ozturk I, Sinha A (2020) Revisiting the role of renewable and non-renewable energy consumption on Turkey's ecological footprint: Evidence from Quantile ARDL approach. Sustain Cities Soc 102138

Schulze PC (2002) I= PBAT. Ecol Econ 40(2):149-150

Stern DI (2004) The rise and fall of the environmental Kuznets curve. World Dev 32(8):1419-1439

Ulucak R, Khan SUD (2020) Relationship between energy intensity and $\mathrm{CO} 2$ emissions: does economic policy matter? Sustain Dev. https://doi.org/10.1002/sd.2098

Usman O, Elsalih O, Koshadh O (2019) Current Issues in Tourism Environmental performance and tourism development in EU-28 Countries : the role of institutional quality. Curr Issue Tour 1-6. https://doi.org/10.1080/13683500.2019.1635092

Wang ML, Wang W, Du SY, Li CF, He Z (2020) Causal relationships between carbon dioxide emissions and economic factors: evidence from China. Sustain Dev 28(1):73-82

York R, Rosa EA, Dietz T (2003) STIRPAT, IPAT and ImPACT: analytic tools for unpacking the driving forces of environmental impacts. Ecol Econ 46(3):351-365

Publisher's note Springer Nature remains neutral with regard to jurisdictional claims in published maps and institutional affiliations. 